\title{
Attitudes towards predictive testing in Huntington's disease: a recent survey in Belgium*
}

\author{
G EVERS-KIEBOOMS, J J CASSIMAN, AND H VAN DEN BERGHE \\ From the Centre for Human Genetics, Gasthuisberg, $O \& N$, Herestraat 49, 3000 Leuven, Belgium.
}

SUMmARY After the publication of evidence of the existence of a DNA polymorphism closely linked to the gene for Huntington's disease, attitudes towards predictive testing for Huntington's disease were evaluated in Belgium in a group of persons who are at risk for the disease and in a smaller group of their partners. The percentage of persons at risk who planned to take the test was smaller than in many previously published studies. Our results revealed a lack of association between the intention to take the test and social or demographic variables. Specific attention was paid to the difference in intention between a person at risk and his or her partner and to the opinions about the way the decision to take the test should be made.

In 1983 Gusella et al ${ }^{1}$ published evidence for the existence of a DNA polymorphism closely linked to the gene for Huntington's disease. Although additional research is needed before this marker or any other can be put into clinical use, it is clear that in the near future predictive testing for Huntington's disease will be technically possible. The prospect that asymptomatic persons can be tested for the presence of a serious, lethal, neurodegenerative disorder with onset in middle age, for which there is no real treatment, creates a difficult situation which is so far unique in medical history. After the communication of the results of predictive testing, the 'risk status' of half of the persons at risk is suddenly replaced by a 'carrier status'. Being told of the carrier status includes the knowledge of being in the presymptomatic phase of Huntington's disease, although there is no way to predict when the first symptoms will appear.

The decision to take such a test has far reaching consequences. There is no escape after predictive testing; once a person receives the information, there is no way of obliterating the knowledge. Therefore, a careful analysis of all the implications of predictive testing is necessary on the individual

${ }^{*}$ Based on a paper presented at the conference of the International Huntington Association, Lille, France, 8-11 September 1985.

Received for publication 9 December 1985.

Revised version accepted for publication 30 January 1986. level as well as on the population level. It also requires new evaluation of attitudes towards predictive testing, which has now become a realistic possibility in the near future. We report results of a recent survey in Belgium on the attitudes towards predictive testing in a group of persons who are at risk for Huntington's disease and in a smaller group of their partners.

\section{Sample composition and methodology}

In March 1984 the Centre for Human Genetics of the University of Leuven organised an information meeting in collaboration with the Belgian Huntington Association for a limited number of persons. The purposes of this meeting were: (1) to explain the recent findings on the linkage of a DNA polymorphism with Huntington's disease and its implications for possible predictive testing; and (2) to ask for the cooperation of persons at risk and their partners in a research project with the primary aim of investigating the prevalence of the DNA polymorphism in Belgian Huntington's disease families, in order to explore the possible use of this polymorphism in a predictive test. For that purpose, only longstanding members of the Huntington Association, from a limited number of families, selected on the basis of pedigree data and to a lesser extent of educational level and emotional stability, 
were invited. These persons were then considered as 'contact' persons capable of informing the others and of asking for the cooperation of all relevant family members (affected persons, persons at risk, and partners). Within these families full cooperation from most members was readily obtained.

From all cooperating subjects a blood sample was taken for DNA analysis and a questionnaire was given to the persons at risk and to the partners of affected subjects and of those at risk. The main aim of the questionnaire was to evaluate the knowledge and expectations concerning the predictive test.

This questionnaire comprised four parts: (1) identification variables; (2) information concerning the disease in the affected parent; (3) general knowledge on the genetic aspects of the disease and specific knowledge concerning the test; and (4) attitudes towards predictive testing.

Information was obtained from 49 persons at risk and 27 partners; 28 of these, who are active members of the Association, received additional information during a special meeting, the other 48 did not attend this meeting and only a subgroup of them are active members of the Huntington Association. Table 1 shows the sample composition as a function of the risk situation and as a function of the attendance at the meeting.

\section{Results and discussion}

\section{SOCIODEMOGRAPHIC INFORMATION}

Since attitudes towards predictive testing may be influenced by social and demographic data, we first present a detailed description of the respondents. The percentage of male and female respondents was almost equal, in the total group as well as in the subgroups. About $67 \%$ of the total group were between 20 and 39 years old. Ten percent of the persons at risk were less than 20 years old, $35 \%$ between 20 and 29 years, $37 \%$ between 30 and 39 years, and $18 \%$ were 40 years or older. In the group $\stackrel{\overparen{Q}}{?}$ of partners, the mean age was slightly higher. Eleven percent of the subjects who received addi- $\frac{\vec{D}}{+}$ tional information were less than 20 years old, $28 \%$ 을 were between 20 and 29 years, $43 \%$ were between 흠. 30 and 39 years, and $18 \%$ were 40 years or older. The mean age of the subjects who received noळ additional information was slightly higher. Since only active Association members, who could be $\overrightarrow{0}$ considered as 'key persons' in their family, were invited to the meeting, it is not surprising that the $\vec{\omega}$ educational level was higher in this group. The educational level was higher in the group of persons at risk than in the group of partners (table 2). Sixty-i three percent of the persons at risk were married at + or the time of the survey, $33 \%$ were unmarried (never married), and $4 \%$ were divorced. In the group of $\mathrm{N}$ partners, about $70 \%$ had one or more children. Ino the married group of persons at risk about twothirds had one or more children (table 3 ).

INTENTIONS REGARDING THE USE OF PREDICTIVE TESTING

A comparison of the intentions towards the use of predictive testing could be made between the group of subjects at risk and the group of partners. Theo data were gathered by means of a direct questionœ "Would you want to take a predictive test should it become available?" to all those at risk. If the answer $\overrightarrow{\vec{*}}$ was yes, we asked whether they intended to make 3 use of it immediately it became available. All partners of persons at risk were asked if they wouldo be in favour of a predictive test for their partner should it become available. If so, they were asked if they were in favour of immediate testing as soon as:this became possible. The figure shows that about the same percentage of persons at risk and partnerso were in favour of using the predictive test. The mainß difference was that relatively more partners were ino

TABLE 1 Sample composition: risk situation and information received.

\begin{tabular}{|c|c|c|c|c|c|}
\hline & \multicolumn{2}{|c|}{$\begin{array}{l}\text { Additional information received } \\
\text { during special meeting }\end{array}$} & \multicolumn{2}{|c|}{$\begin{array}{l}\text { No additional information } \\
\text { received }\end{array}$} & \multirow[t]{2}{*}{ Total } \\
\hline & No & $(\%)$ & No & $(\%)$ & \\
\hline \multicolumn{6}{|l|}{ At risk } \\
\hline $50 \%$ risk & 14 & $(50 \cdot 5)$ & 27 & $(56 \cdot 2)$ & 41 \\
\hline $25 \%$ risk & 4 & $(14 \cdot 3)$ & 4 & $(8 \cdot 3)$ & 8 \\
\hline \multirow{4}{*}{$\begin{array}{l}\text { Partner } \\
\text { of an affected person } \\
\text { of an at risk person }(50 \%) \\
\text { of an at risk person }(25 \%)\end{array}$} & & & & & \\
\hline & 3 & $(10 \cdot 7)$ & 4 & $(8 \cdot 3)$ & 7 \\
\hline & 5 & $(17 \cdot 9)$ & 13 & $(27 \cdot 1)$ & 18 \\
\hline & 2 & $(7 \cdot 1)$ & 0 & & 2 \\
\hline Total & 28 & $(100)$ & 48 & $(100)$ & 76 \\
\hline
\end{tabular}


TABLE 2 Social and demographic information: educational level.

\begin{tabular}{|c|c|c|c|c|c|c|c|c|c|c|}
\hline & \multirow{2}{*}{\multicolumn{2}{|c|}{$\begin{array}{l}\text { Total } \\
\text { group }\end{array}$}} & \multicolumn{4}{|c|}{ Information } & \multicolumn{4}{|c|}{ Risk situation } \\
\hline & & & \multicolumn{2}{|c|}{$\begin{array}{l}\text { Additional } \\
\text { information }\end{array}$} & \multicolumn{2}{|c|}{$\begin{array}{l}\text { No additional } \\
\text { information }\end{array}$} & \multicolumn{2}{|c|}{$\begin{array}{l}\text { Person } \\
\text { at risk }\end{array}$} & \multicolumn{2}{|c|}{$\begin{array}{l}\text { Partner of } \\
\text { person at risk } \\
\text { or affected person }\end{array}$} \\
\hline & No & $(\%)$ & No & $(\%)$ & No & $(\%)$ & No & $(\%)$ & No & $(\%)$ \\
\hline Only Primary school & 22 & $(29.9)$ & 4 & $(14 \cdot 3)$ & 18 & $(37 \cdot 5)$ & 12 & $(24 \cdot 5)$ & 10 & $(37 \cdot 0)$ \\
\hline$<$ High school & 14 & $(18 \cdot 4)$ & 3 & $(10.7)$ & 11 & $(22.9)$ & 9 & $(18 \cdot 4)$ & 5 & $(18 \cdot 5)$ \\
\hline High school & 19 & $(25 \cdot())$ & 6 & $(21 \cdot 4)$ & 13 & $(27 \cdot 1)$ & 13 & $(26 \cdot 5)$ & 6 & $(22 \cdot 2)$ \\
\hline$>$ High school & 21 & $(27 \cdot 6)$ & 15 & $(53 \cdot 6)$ & 6 & $(12 \cdot 5)$ & 15 & $(30 \cdot 6)$ & 6 & $(22 \cdot 2)$ \\
\hline Total & 76 & & 28 & & 48 & & 49 & & 27 & \\
\hline
\end{tabular}

TABLE 3 Social and demographic information: number of children.

\begin{tabular}{|c|c|c|c|c|c|c|c|c|c|c|}
\hline & \multirow{2}{*}{\multicolumn{2}{|c|}{$\begin{array}{l}\text { Total } \\
\text { group }\end{array}$}} & \multicolumn{4}{|c|}{ Information } & \multicolumn{4}{|c|}{ Risk situation } \\
\hline & & & \multicolumn{2}{|c|}{$\begin{array}{l}\text { Additional } \\
\text { information }\end{array}$} & \multicolumn{2}{|c|}{$\begin{array}{l}\text { No additional } \\
\text { information }\end{array}$} & \multicolumn{2}{|c|}{$\begin{array}{l}\text { Person } \\
\text { at risk }\end{array}$} & \multicolumn{2}{|c|}{$\begin{array}{l}\text { Partner of } \\
\text { person at risk } \\
\text { or affected person }\end{array}$} \\
\hline & No & $(\%)$ & No & $(\%)$ & No & $(\%)$ & No & $(\%)$ & No & $(\%)$ \\
\hline No children, never married & 17 & $(22 \cdot 4)$ & 7 & $(25 \cdot())$ & 10 & $(20 \cdot 8)$ & 16 & $(32 \cdot 6)$ & 1 & $(3 \cdot 7)$ \\
\hline No children. married & 18 & $(23 \cdot 7)$ & 10 & $(37.7)$ & 8 & $(16 \cdot 7)$ & 11 & $(22 \cdot 4)$ & 7 & $(25.9)$ \\
\hline One child & 15 & $(19 \cdot 7)$ & 8 & $(28.6)$ & 7 & $(14 \cdot 6)$ & 8 & $(16 \cdot 3)$ & 7 & $(25.9)$ \\
\hline Two children & 14 & $(18 \cdot 4)$ & 1 & $(3 \cdot 6)$ & 13 & $(27 \cdot 1)$ & 9 & $(18 \cdot 4)$ & 5 & $(18 \cdot 5)$ \\
\hline Three or more children & 12 & $(15 \cdot 8)$ & 2 & $(7 \cdot 1)$ & 10 & $(20 \cdot 8)$ & 5 & $(10 \cdot 2)$ & 7 & $(25.9)$ \\
\hline Total & 76 & & 28 & & 48 & & 49 & & 27 & \\
\hline
\end{tabular}

\section{Subjects at risk}

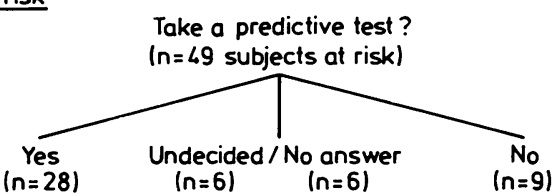

Immediately when available?

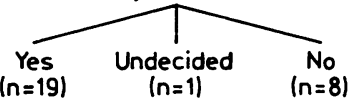

$(n=19) \quad(n=1) \quad(n=8)$

Partners of subjects at risk

In favour of a predictive test?

( $n=20$ partners of a subject at risk)

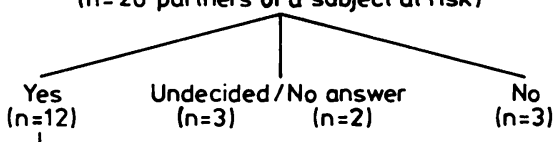

Immediately when available?

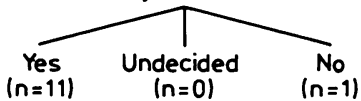

FIGURE Attitudes towards use of the predictive test. favour of testing 'immediately' instead of postponing the test (table 4).

To gain more insight into the motivation for taking a predictive test, we asked the subjects at risk and their partners to give reasons why they wanted or did not want a predictive test. This was formulated as an open ended question, in order to elicit a spontaneous answer and to exclude suggestion. An overview of all reasons given by those who wanted the test is given in table 5 . The main reason for undergoing a test was to have 'certainty' instead of uncertainty and anxiety. The nine subjects at risk who did not plan to take the test gave the following reasons for rejecting it: a positive result would be too emotionally loaded $(n=5)$, the absence of

TABLE 4 Attitudes towards use of a predictive test.

\begin{tabular}{|c|c|c|}
\hline & $\begin{array}{l}\text { Persons at risk } \\
(n=49)\end{array}$ & $\begin{array}{l}\text { Partners of } \\
\text { persons at risk } \\
(n=20)\end{array}$ \\
\hline Take the test when available & $39 \%)$ & $55 \%)$ \\
\hline Take the test, undecided when & $2 \%$ & $0 \%$ \\
\hline Take the test. but not immediately & $16 \%$ & $5 \%$ \\
\hline Undecided & $25 \%$ & $25 \%$ \\
\hline Not take the test & $18 \%$ & $15 \%$ \\
\hline
\end{tabular}


TABLE 5 Reasons persons at risk who want the test gave for taking a predictive test and reasons partners gave for wanting a predictive test for their husband/wife.

\begin{tabular}{|c|c|c|c|c|}
\hline & \multicolumn{2}{|c|}{$\begin{array}{l}\text { Person at risk } \\
(n=28)\end{array}$} & \multicolumn{2}{|c|}{$\begin{array}{l}\text { Partner } \\
(n=12)\end{array}$} \\
\hline & No & $(\%)$ & No & $(\%)$ \\
\hline To have 'certainty' & 8 & (29) & 4 & (33) \\
\hline $\begin{array}{l}\text { To make decisions concerning further } \\
\text { children }\end{array}$ & 6 & (21) & 4 & (33) \\
\hline To make decisions concerning marrjage & 5 & $(18)$ & 1 & (8) \\
\hline To inform the children & 5 & (18) & 0 & (0) \\
\hline To plan a career & 3 & (11) & 1 & $(8)$ \\
\hline $\begin{array}{l}\text { To look for guidance if the test is } \\
\text { positive }\end{array}$ & 3 & (11) & 2 & (17) \\
\hline $\begin{array}{l}\text { To start treatment if the test is } \\
\text { positive }\end{array}$ & 3 & (11) & 2 & (17) \\
\hline For financial reasons & 2 & (7) & 1 & (8) \\
\hline To reduce the frequency of $\mathrm{HD}$ & 0 & ((0) & 1 & (8) \\
\hline No reason mentioned & 9 & (32) & 5 & (42) \\
\hline
\end{tabular}

treatment $(n=4)$, or the subjective feeling that they did not carry the gene $(n=1)$. The fact that a positive result would be too emotionally loaded was also the reason why one of the partners rejected the test. Of the two other partners who rejected the predictive test, one did so because of the absence of treatment and the last one did not give a reason.

We also investigated whether there was any association between the intention to take the predictive test and some social and demographic variables. For the group of persons at risk there seemed to be no association with sex, age, educational level, risk level, and the presence or absence of children. There was an association between the intention to take the test and the presence or absence at the information meeting. The fact that those present at the meeting were active members of the Huntington Association is probably one of the factors responsible for this association. There was also an association with the age at onset of Huntington's disease in the affected parent; the younger the father or mother of a subject at risk became affected, the stronger the intention to take the test seemed to be. Since, however, onset of the disease at a younger age may imply a much stronger influence on the life of the children, it may not be the age as such but other associated factors which may be responsible for this apparent association with age of onset.

An overview of the rank correlations (Kendall tau coefficients) between the strength of the intention to take the test and some other variables is presented in table 6. It is clear that the pattern of correlations was different for the partners. Here we found a significant role of educational level and of the presence or absence of children. Partners with a lower educational level were more in favour of a
TABLE 6 Rank correlations (Kendall tau) between attitudes towards predictive testing and some demographic and other: variables.

\begin{tabular}{|c|c|c|}
\hline & $\begin{array}{l}\text { Persons at risk } \\
(n=49)\end{array}$ & $\begin{array}{l}\text { Partners of } \\
\text { persons at risk } \\
(n=20)\end{array}$ \\
\hline $\begin{array}{l}\text { Sex } \\
\text { Age } \\
\text { Educational level } \\
\text { Risk level }(25 \text { to } 50 \%) \\
\text { Absence or presence of } \\
\text { children } \\
\text { Attendance at the information } \\
\text { meeting } \\
\text { Age at onset of the disease in } \\
\text { the affected parent }\end{array}$ & $\begin{array}{r}0 \cdot(003 \\
0 \cdot(056 \\
-0 \cdot 020 \\
0 \cdot 030 \\
-0 \cdot 007 \\
0 \cdot 396(p=0 \cdot(0) 3) \\
-0 \cdot 35(p=0 \cdot 016)\end{array}$ & $\begin{array}{r}0.17 \\
0.20 \\
-0.43(p=0.029)\end{array}$ \\
\hline
\end{tabular}

predictive test in their husband or wife at risk. The presence or absence of children also played an important role in the attitude of the partners? towards predictive testing. If they had children they $\overrightarrow{\vec{Z}}$ were more in favour of a predictive test immediately it became available. In contrast to the results for the subjects at risk themselves, we did not find an $\vec{\infty}$ association with the presence at or absence from the. $v$ information meeting.

Since the difference in intention between a person at risk and his or her partner will be a source of additional stress in the decision making process too take the test, we investigated the agreement withinळ 18 married couples, in which both partners filled out the questionnaire. Completely concordant viewso with regard to the test occurred in only seven out of 18 couples: in five couples both partners were in favour of taking the predictive test immediately it became available and in two couples both partners were against the test. In seven couples one of the partners was undecided about the test, while the other had a clear attitude. In the last three couplesi the subject at risk and his or her partner had completely opposite views: one person at risko wanted the test immediately while the partner was? against the test, and two persons at risk were againsto the test while the partner was in favour of immediate testing.

We also investigated some views on the way then decision to take the test should be made. Only $73 \%$ 어 of those at risk were convinced that the decision to $\sigma$ take the test should be made after discussion with their partner. Because of the implications of the tes? result for the partner of a subject at risk, it ise difficult to understand this attitude. In the group of persons at risk as well as in the group of partners fewer than $50 \%$ of the respondents agreed that the decision should be made after consultation with one $\frac{?}{\mathbb{D}}$ or more experts who were well aware of the possible problems. 


\section{Conclusions}

The percentage of persons at risk who planned to take the test was smaller than in many other previously published studies. ${ }^{2-6}$ In our study $57 \%$ of persons at risk would want to take the test while $60 \%$ of the partners were in favour of it. The main difference between those at risk and their partners was that the partners were more in favour of taking the test immediately it was available.

For the subjects at risk there was no association between the intention to take the test and the social and demographic variables in this survey. This lack of association was also shown in the study of Schoenfeld et al. ${ }^{3}$ Our results do not confirm the hypothesis that older persons at risk are more in favour of predictive testing because the 'chance of escaping' increases so that they can provide 'good news' for their children. In the group of partners, an association with educational level and with the presence or absence of children was found. Additional research on a large sample of persons at risk and partners is needed to get more insight into the intentions and motivation towards a predictive test. In our survey we had insufficient data regarding the experience of the disease in the affected parent. The role of these experiences and of personality variables should also be assessed in future research.

A very intriguing finding was the fact that more than half of the respondents did not agree that the decision to take the test should be taken after consultation with experts. Because of the consequences of a positive test result, we feel very strongly that professionals should assist persons at risk and their partners during the decision making process to help them to make the appropriate decision.

Notwithstanding the fact that "addressing the problematic issues should not overwhelm attention to the tremendous benefits that this new knowledge can bring", 7 the new situation clearly produces a need for more interdisciplinary collaboration between genetic counsellors, psychologists, social workers, representatives of Huntington's disease associations, and the families concerned to ensure that this new diagnostic possibility is of positive value.

We thank the Belgian Huntington Association for their collaboration which was a conditio sine qua non in performing this study. We especially thank Mrs T Cloostermans and Mrs A Boogaerts and all the persons at risk and partners who filled out the questionnaires.

\section{References}

1 Gusella JF, Wexler NS, Conneally PM, et al. A polymorphic DNA marker for Huntington's disease. Nature 1983;306:234-8.

2 Barette J, Marsden CD. Attitudes of families to some aspects of Huntington's chorea. Psychol Med 1979:9:327-36.

${ }^{3}$ Schoenfeld M. Myers RH. Berkman B. Clark E. Potential impact of predictive test on the gene frequency of Huntington's disease. Am J Med Genet 1984;18:423-9.

+ Stern R. Eldridge R. Attitude of patients and their relatives to Huntington's disease. J Med Genet 1975:12:217-23.

5 Teltscher B, Polgar S. Objective knowledge about Huntington's disease and attitudes towards predictive tests of persons at risk. J Med Genet 1981;18:31-9.

- Tyler A. Harper PS. Attitudes of subjects at risk and their relatives towards genetic counselling in Huntington's chorea. J Med Genet 1983;20:179-88.

7 Wexler NS, Conneally PM, Housman D, Gusella JF. Editorial. A DNA polymorphism for Huntington's disease marks the future. Arch Neurol 1985:42:20-4.

Correspondence and requests for reprints to Dr G Evers-Kiebooms, Centre for Human Genetics, Campus Gasthuisberg, O \& N, Herestraat 49, 3000 Leuven, Belgium. 